\title{
Alcohol use and HIV serostatus of partner predict high-risk sexual behavior among patients receiving antiretroviral therapy in South Western Uganda
}

Francis Bajunirwe ${ }^{1 *}$, David R Bangsberg ${ }^{2,3}$ and Ajay K Sethi ${ }^{4}$

\begin{abstract}
Background: Antiretroviral treatment restores the physical and immunological function for patients with HIV/AIDS and the return of sexual desire. The frequency and correlates of sexual activity among patients receiving ART have not been widely studied. There is concern that widespread availability of ART may result in sexual disinhibition including practice of high-risk sexual behavior. We determined the correlates of sexual activity and high-risk sexual behavior in an ART-treated population in rural and urban Uganda.

Methods: We conducted a cross-sectional study among 329 ART-treated adult patients at two hospitals, one located in rural and another in urban western Uganda. We collected data on sexual activity, frequency of condom use, pregnancy, viral load (VL) and CD4. Patients were considered sexually active if they had had sexual intercourse in the last 6 months. Any unprotected sex was considered high-risk sex. A two-stage logistic regression was performed to determine factors associated with sexual activity and high-risk sex among those sexually active.

Results: Overall, 222 (67\%) patients were women, 138 (41.2\%) had been on ART for at least one year, and 168 (51.4\%) were sexually active of whom $127(75.6 \%)$ used condoms at the last intercourse. Younger age (<=30 years) (Odds ratio; $\mathrm{OR}=2.3,95 \% \mathrm{Cl}$ 1.2, 4.2), higher monthly income ( $\mathrm{OR}=4.1,95 \% \mathrm{Cl}$ 2.4, 7.4), and being married (OR=22.7, $95 \% \mathrm{Cl} 8.2,62.9)$ were associated with being sexually active. Undetectable VL, CD4 count and treatment duration were not significantly associated with sexual activity. Among the sexually active, alcohol consumption $(\mathrm{OR}=3.3$, $95 \% \mathrm{Cl} 1.2,9.1)$ and unknown serostatus of partner ( $\mathrm{OR}=5.8,95 \% \mathrm{Cl} 1.5,21.4)$ were significant predictors of high-risk sexual behavior. The frequency of unprotected sex at the last intercourse was $25.9 \%$ and $22.1 \%$ among the men and women respectively and was not significantly different ( $p$ value for chi square test $=0.59$ ).

Conclusion: Younger persons receiving ART are more likely to be sexually active. ART clients are more likely to engage in unprotected sex when sero-status of partner is unknown or report use of alcohol. Counseling on alcohol use and disclosure of sero-status may be useful in reducing high risk sexual behavior.
\end{abstract}

Keywords: High-risk sexual behavior, Antiretroviral treatment, Rural and urban, Uganda

\footnotetext{
*Correspondence: fbaj@yahoo.com

'Department of Community Health, Mbarara University of Science and

Technology, P.O. BOX 1410, Mbarara, Uganda

Full list of author information is available at the end of the article
} 


\section{Background}

Antiretroviral therapy (ART) restores quality of life, physical functioning for majority of HIV-infected individuals [1-3] and return of sexual desire and resumption of sexual activity [4]. Safe sexual practice among HIV infected patients includes consistent use of condoms and is encouraged as part of positive living. There is widespread concern that large-scale availability of ART may result in sexual behavior disinhibition [5], possibly because HIV infected patients may perceive themselves as not infectious. In a U.S. study of patients attending primary HIV care, the belief that an undetectable viral load reduces infectiousness was significantly associated with high-risk behavior such as unprotected sexual intercourse [6]. Similarly, uninfected individuals may have lower perceived threat of HIV acquisition because of the availability of the treatments, believe that its use associated with lower infectiousness, and possibly engage in high-risk sexual behavior. Several studies have shown that initiation of ART does not necessarily result in risky sexual behavior, and in fact results in an increase in safer sexual practices [7], with up to $70 \%$ reduction in risky sexual behavior practices 6 months after initiation of ART. However the reports have been conflicting with some data suggesting that risky behavior may instead increase [5].

Based on the paradigm of treatment as prevention, one would expect that widespread use of ART will reduce the incidence of HIV transmission by reducing the community viral load [8]. However, mathematical models show effectiveness of combination prevention efforts will be dampened if large-scale treatment is accompanied with sexual behavioral disinhibition [9-11]. Population-based studies in Uganda show that there has been an increase in the number of casual partners accompanied by a decline in condom use among those in the middle age groups [12]. Data from Uganda also suggest that HIV incidence and prevalence are no longer on the decline as had previously been experienced [13], though the role of changing sexual behavior was not clearly explained.

The predictors of sexual activity and high-risk sexual behavior have not been adequately assessed among ART patients. This would be useful as it might identify individual-level risk factors to address during sexual behavior counseling. Specifically, alcohol consumption has been independently associated with HIV infection [14], adverse outcomes such as non adherence [15] and highrisk sexual behaviors in the general population [16], but fewer studies have been conducted among patients receiving ART particularly in resource-limited and rural settings. To determine these predictors, we conducted a cross-sectional study to determine the prevalence and correlates of sexual activity among patients receiving ART and to determine the factors associated with high-risk sexual behavior among those who are sexually active.

\section{Methods}

\section{Study design and setting}

We conducted a cross-sectional study among patients receiving ART at government supported health facilities in a rural (Sheema) and urban (Mbarara) district all in south western Uganda. Data were collected from government facilities in the district at Kitagata and Mbarara Hospitals located in Sheema and Mbarara districts, respectively. The two facilities are the largest hospitals in their respective districts; however, Sheema is rural and Mbarara is urbanized. Patients were eligible to participate if they had completed at least 6 months of antiretroviral therapy. Patients were enrolled consecutively and data was collected between April and October 2006.

Research assistants administered questionnaires to the study participants in the local language of Runyankore. Blood samples were also drawn at the same time to determine biological measurements. Data was then entered into Epidata and analyzed using STATA version 11 (StataCorp, College Station, Texas).

\section{Measurements and data analysis}

We collected data on sexual activity, consistency of condom use, number of sexual partners and rating of current interest in sexual activity. Respondents were considered sexually active if they reported sexual intercourse in the last 6 months. Any unprotected sex was considered as high-risk sexual activity. To determine high-risk sexual behavior, participants were asked "The last time you had sexual intercourse, was a condom used?" Blood samples were collected to determine viral load and CD4 count. Viral load was considered undetectable if plasma HIV RNA concentration was $<50$ copies per milliliter (Roche, Amplicor). We compared baseline characteristics between the rural and urban sites using chi-square testing for the categorical variables and t-test for the continuous variables. We performed separate logistic regression analysis with sexual activity and unprotected sex as dependant variables and several factors including age, marital status, gender, place of residence (rural versus urban), monthly income, educational level, CD4 count, viral load, ART treatment duration and alcohol consumption were considered as predictors. We collected data on consumption of all alcohol containing beverages and any consumption of an alcohol containing beverage in the last 6 months was considered as an exposure. We report odds ratios and corresponding $95 \%$ confidence intervals.

\section{Ethics}

The study was submitted to and approved by the Mbarara University of Science and Technology Institutional Review 
Board and final permission was obtained from the Uganda National Council of Science and Technology. We obtained informed written consent from all participants before they were enrolled in the study.

\section{Results}

We interviewed a total of 329 patients at the two hospitals of the 334 that were approached. Of those who accepted to participate, 175 (53\%) were at the rural site and the $154(47 \%)$ were at the urban hospital (Table 1). Majority of the patients at both sites were female. Also, the two populations were similar in terms of literacy rates, monthly income and level of education. In comparison with patients at the rural site, those at the urban site had been on treatment for significantly longer, were less likely to drink alcohol and less likely to report a

\section{Table 1 Baseline characteristics of patients receiving} antiretroviral treatment at Kitagata and Mbarara Hospitals in southwestern Uganda, April to October 2006

\begin{tabular}{|c|c|c|c|}
\hline Characteristic & $\begin{array}{l}\text { Kitagata } \\
\text { hospital } \\
\text { (Rural) } \\
n=175\end{array}$ & $\begin{array}{l}\text { Mbarara } \\
\text { hospital } \\
\text { (Urban) } \\
n=154\end{array}$ & $p$ value \\
\hline Aged $=<30$ years & $28(16.0)$ & $28(18.1)$ & 0.25 \\
\hline Female & $111(63.4)$ & $111(72.1)$ & 0.09 \\
\hline Can write & $145(82.8)$ & $130(83.4)$ & 0.80 \\
\hline Can read & $144(82.3)$ & $133(85.1)$ & 0.38 \\
\hline \multicolumn{4}{|l|}{ Marital status } \\
\hline Widowed & $74(42.5)$ & $54(34.8)$ & \\
\hline Separated/Divorce & $21(12.1)$ & $17(10.9)$ & \\
\hline Never married & $4(2.3)$ & $15(9.7)$ & \\
\hline Married Polygamous & $18(10.3)$ & $12(7.7)$ & \\
\hline Married monogamous & $57(32.8)$ & $57(36.7)$ & 0.04 \\
\hline \multicolumn{4}{|l|}{ Monthly income } \\
\hline Less than 5 USD & 85 (48.6) & $63(41.7)$ & \\
\hline 5 to 30 USD & $49(28.0)$ & $45(29.8)$ & \\
\hline Over 30 USD & $41(23.4)$ & $43(28.5)$ & 0.42 \\
\hline \multicolumn{4}{|l|}{ Education } \\
\hline None & $22(12.6)$ & $16(10.5)$ & \\
\hline Seven years or less & $93(53.1)$ & $68(44.4)$ & \\
\hline More than 7 years & $60(34.3)$ & $69(45.1)$ & 0.14 \\
\hline \multicolumn{4}{|l|}{ ART Treatment duration } \\
\hline One year or less & $134(76.6)$ & $58(37.4)$ & \\
\hline More than one year & $41(23.4)$ & $97(62.6)$ & 0.001 \\
\hline Alcohol use in last 6 months & $21(12.0)$ & $8(5.2)$ & 0.03 \\
\hline Non-Adherent using 3 day self report & $26(14.9)$ & $5(3.3)$ & $<0.001$ \\
\hline Viral load undetectable & $147(84.0)$ & $108(72.5)$ & 0.012 \\
\hline \multicolumn{4}{|l|}{ CD4 cell count } \\
\hline 200 cells or less & $48(27.4)$ & $19(15.7)$ & \\
\hline More than 200 cells & $127(72.6)$ & $102(84.3)$ & 0.02 \\
\hline
\end{tabular}

missed pill over the last three days, had higher proportion of patients with CD4 count above 200 cells per ml but a lower proportion of patients with undetectable viral load.

Comparison of sexual behavior among males and females Overall 168 (51.4\%) patients were sexually active in the previous 6 months. Among the men, 75.7\% of them were sexually active compared to $39.4 \%$ among the females and the difference was statistically significant (chi square $\mathrm{p}$ value $<0.0001$, see Table 2 ). The men were also more likely to report higher interest in sex and an increased interest in sexual activity since ART started.

Among the sexually active participants ( $\mathrm{n}=168$ or $51.4 \%)$, the men had a significantly larger number of lifetime sexual partners (8.4 versus 3.2 among men and women respectively, $p$ value for Mann-Whitney test $<0.001$ ), and a larger number of sexual partners over the last six months (1.2 versus 0.8 among men and women respectively, $p$ value for Mann-Whitney test $<0.001)$. The frequency of unprotected sex at the last intercourse was $25.9 \%$ and $22.1 \%$ among the men and women respectively

Table 2 Comparison of sexual behavior characteristics among men and women receiving antiretroviral treatment in southwestern Uganda, April to October 2006

\begin{tabular}{|c|c|c|c|}
\hline Characteristic & $\begin{array}{l}\text { Male } \\
\mathrm{n}=107\end{array}$ & $\begin{array}{l}\text { Female } \\
n=222\end{array}$ & $p$ value \\
\hline Sexually active & $81(75.7 \%)$ & 87 (39.4\%) & $<0.0001$ \\
\hline \multicolumn{4}{|l|}{ Current interest in sex } \\
\hline Low & $48(44.9 \%)$ & 155 (69.8\%) & \\
\hline Normal & $56(52.3 \%)$ & $60(27.0 \%)$ & \\
\hline High & $3(2.8 \%)$ & $7(3.2 \%)$ & $<0.0001$ \\
\hline \multicolumn{4}{|l|}{ Interest in sex since ART } \\
\hline \multicolumn{4}{|l|}{ started } \\
\hline Decreased & $36(33.9 \%)$ & $125(56.3 \%)$ & \\
\hline Remained the same & $50(47.2 \%)$ & $77(34.7 \%)$ & $<0.0001$ \\
\hline \multirow[t]{3}{*}{ Increased } & $20(18.9 \%)$ & $20(9.0 \%)$ & \\
\hline & \multicolumn{2}{|c|}{$\begin{array}{l}\text { Among sexually active } \\
\text { only } n=168\end{array}$} & \\
\hline & Male $=81$ & Female $=87$ & \\
\hline $\begin{array}{l}\text { Mean number of lifetime } \\
\text { sexual partners (median) }\end{array}$ & $8.4(3)$ & $3.2(2)$ & $<0.001^{*}$ \\
\hline $\begin{array}{l}\text { Mean number of sexual partners } \\
\text { over the last } 6 \text { months (Median) }\end{array}$ & $1.2(1)$ & $0.98(1)$ & $<0.001^{*}$ \\
\hline $\begin{array}{l}\text { Unprotected sex at last intercourse } \\
\text { (among sexually active only) }\end{array}$ & $21(25.9 \%)$ & $19(22.1 \%)$ & 0.59 \\
\hline \multicolumn{4}{|l|}{ Sero status of partner at last } \\
\hline intercourse & $27(33.3 \%)$ & $5(5.8 \%)$ & \\
\hline Negative & $37(45.7 \%)$ & $42(48.8 \%)$ & \\
\hline Positive & $17(21.0 \%)$ & $39(45.4 \%)$ & $<0.001$ \\
\hline Unknown & & & \\
\hline
\end{tabular}


and was not significantly different ( $p$ value for chi square test $=0.59$ ). However, the women were more likely to report intercourse with a partner of unknown serostatus at their last intercourse compared to the men $(45.4 \%$ versus $21.0 \%$ respectively, chi square p value $<0.0001$ ).

Predictors of sexual activity and high-risk sexual behavior The younger respondents (those aged 30 years or less) were more likely to engage in sexual activity compared to older patients. Women were $80 \%$ less likely to be sexually active compared to the men $(\mathrm{OR}=0.2,95 \% \mathrm{CI}$ $0.12,0.35)$. In increasing order of magnitude, separated/ divorced, never married, married polygamous and married monogamous were significantly more likely to be sexually active compared to the widowed (Table 3). Respondents with more education and in the higher income brackets were also more likely to be sexually active.

Among the sexually active respondents, alcohol use and serostatus of sexual partner at intercourse were significantly associated with high-risk sexual behavior. Any alcohol use in the past 6 months was associated with a three-fold increase in the odds of unprotected sex compared to no alcohol use (OR=3.3, 95\% CI 1.2, 9.1). Respondents who had sexual partners of unknown serostatus had an almost 6-fold increase in the odds of unprotected sex compared to those partners who were known to be HIV negative (OR=5.8, 95\% CI 1.5, 21.4). Overall, respondents with a partner of known serostatus (negative or positive) were less likely to report unprotected sexual intercourse at last sex compared to those with partners of unknown serostatus $(\mathrm{p}=0.004$, chi square).

In a multivariable logistic regression model (Table 4) to predict high risk sexual behavior and adjusted for age and gender among the sexually active participants, alcohol use and serostatus of partner remained significant predictors.

\section{Discussion}

Our study has shown that any alcohol consumption is associated with high risk sexual behavior among patients receiving antiretroviral therapy in a resource limited setting. These findings are in agreement with several other studies in the literature that have showed the association between alcohol use and high risk sexual behavior and have been combined in a recent meta-analysis [17]. However most of these studies were conducted in the US and other western countries and in fact only 4 of the 27 studies in the meta-analysis were African. Therefore, our study is one of the few studies that have demonstrated the association between alcohol use and high risk sexual behavior among ART clients in sub Saharan Africa. However, the association between alcohol and high-risk sexual behavior is well known and has been demonstrated in different sub groups such male sex workers in Mombasa [18], HIV+ women and men attending primary care clinics [19], fishing villages in Uganda [20,21] and hotel and bar workers in Tanzania [22] and among men who have sex with men (MSM) in Soweto, South Africa [23], few studies have assessed factors associated with high-risk sexual behavior or performed rural and urban comparisons in the same location.

This observational study in western Uganda has also shown that majority of patients receiving antiretroviral therapy are sexually active and sexual activity is especially higher among men than women. The high proportion of sexually active adults is consistent with other studies where the percentage was up to 70\% [24]. The high frequency of sexual activity may be indicative of the restoration of physical functioning following ART which may be accompanied by the desire to live a normal life again which includes sexual activity[2]. However the sexual activity was accompanied by high-risk sexual behavior. The prevalence of unprotected sexual intercourse was over $20 \%$ among both men and women and very similar to a recent study in the urban informal settlement of Kibera in Nairobi, Kenya [25], baseline data in a rural Ugandan cohort [26] but slightly lower than a recent Ethiopian study [27] where more than one third of the ART clients reported risky sexual behavior.

However, our data indicate significant proportion of respondents reported decreased interest in sexual activity once they started ART. Majority of studies have shown a reduction in risky sexual behavior following initiation of ART [28], but to the best of our knowledge, none has shown decreased interest in sexual activity. Anecdotal evidence suggests this may be because a large number of these patients focus on their own recovery once they start on ART.

Our study showed no evidence of association between viral load suppression and high-risk sexual behavior. This finding is in agreement with several studies and the conclusions of a meta-analysis [29]. However, the metaanalysis comprised studies mostly from the developed countries. Since then, several studies among ART clients in sub Saharan Africa have also shown no evidence of the association between detectable or undetectable viral load and high-risk sexual behavior [30,31]. However, studies among MSM in the US have shown that perception of undetectable viral load [32], or reduced concern about HIV transmission following ART [33,34] are associated with higher frequency of unprotected sex. Such studies are yet to be conducted in sub Saharan Africa.

Alternatively, some studies have shown reduced odds of high-risk sexual behavior among patients who had viral load suppression or good adherence to ART [35]. The expectation is patients with viral load suppression 
Table 3 Predictors of sexual activity and high risk sexual activity among patients receiving antiretroviral treatment at Kitagata and Mbarara Hospitals in southwestern Uganda, April to October 2006

\begin{tabular}{|c|c|c|c|c|}
\hline \multirow[b]{2}{*}{ Characteristic } & \multicolumn{2}{|c|}{$\begin{array}{l}\text { Predictors of sexual } \\
\text { activity among all } \\
\text { participants } n=330\end{array}$} & \multicolumn{2}{|c|}{$\begin{array}{l}\text { Predictors of high } \\
\text { risk sexual activity } \\
\text { among sexually } \\
\text { active } n=168\end{array}$} \\
\hline & $\begin{array}{l}\text { Odds } \\
\text { ratio }\end{array}$ & $(95 \% \mathrm{Cl})$ & $\begin{array}{l}\text { Odds } \\
\text { ratio }\end{array}$ & $95 \% \mathrm{Cl}$ \\
\hline \multicolumn{5}{|l|}{ Age } \\
\hline Over 30 years & 1.0 & & 1 & \\
\hline 30 years or younger & $2.3^{*}$ & $1.2,4.2$ & 1.9 & $0.88,4.3$ \\
\hline \multicolumn{5}{|l|}{ Gender } \\
\hline Male & 1.0 & & 1.0 & \\
\hline Female & $0.2^{*}$ & $0.12,0.35$ & 0.81 & $0.39,1.6$ \\
\hline \multicolumn{5}{|l|}{ Marital status } \\
\hline Widowed & 1.0 & & 1.0 & \\
\hline Separated/ Divorced & $4.1^{*}$ & $1.8,9.3$ & 0.50 & $0.10,2.4$ \\
\hline Never married & $6.3^{*}$ & $2.3,17.6$ & 0.93 & $0.17,4.9$ \\
\hline Married polygamous & $22.7^{*}$ & $8.2,62.9$ & 0.89 & $0.24,3.2$ \\
\hline Married monogamous & $40.6^{*}$ & $19.3,85.2$ & 0.60 & $0.20,1.7$ \\
\hline \multicolumn{5}{|l|}{ Residence } \\
\hline Rural & 1.0 & & 1.0 & \\
\hline Urban & 1.4 & $0.92,2.3$ & 0.95 & $0.46,1.9$ \\
\hline \multicolumn{5}{|l|}{ Years of Education } \\
\hline None & 1.0 & & 1.0 & \\
\hline Less than 7 years & $2.3^{*}$ & $1.1,4.9$ & 0.66 & $0.17,2.5$ \\
\hline More than 7 years & $3.9^{*}$ & $1.8,8.6$ & 0.41 & $0.11,1.5$ \\
\hline \multicolumn{5}{|l|}{ Monthly income } \\
\hline Less than 5 USD & 1.0 & & 1.0 & \\
\hline 5 to 30 USD & $2.4^{*}$ & $1.4,4.1$ & 0.64 & $0.26,1.5$ \\
\hline Over 30 USD & $4.1^{*}$ & $2.4,7.4$ & 0.63 & $0.26,1.5$ \\
\hline \multicolumn{5}{|l|}{ CD4 count } \\
\hline Less than 200 & 1.0 & & 1.0 & \\
\hline 200 and over & 1.2 & $0.69,2.1$ & 1.3 & $0.50,3.6$ \\
\hline \multicolumn{5}{|l|}{ VL suppression } \\
\hline Detectable & 1.0 & & 1.0 & \\
\hline Undetectable & 0.41 & $0.12,1.4$ & 1.1 & $0.11,11.6$ \\
\hline \multicolumn{5}{|l|}{3 day self report adherence } \\
\hline Missed a pill & 1.0 & & 1.0 & \\
\hline Missed no pill & 0.81 & $0.38,1.7$ & 0.58 & $0.18,1.8$ \\
\hline \multicolumn{5}{|l|}{ Duration on ART } \\
\hline One year or less & 1.0 & & 1.0 & \\
\hline One to two years & 1.36 & $0.82,2.3$ & 0.44 & $0.18,1.1$ \\
\hline More than 2 years & 1.34 & $0.70,2.6$ & 0.59 & $0.20,1.7$ \\
\hline \multicolumn{5}{|l|}{ Alcohol use } \\
\hline None in past 6 months & 1.0 & & 1.0 & \\
\hline Alcohol in past 6 months & 1.9 & $0.85,4.2$ & $3.3^{*}$ & $1.2,9.1$ \\
\hline Serostatus of partner & & & & \\
\hline
\end{tabular}

Table 3 Predictors of sexual activity and high risk sexual activity among patients receiving antiretroviral treatment at Kitagata and Mbarara Hospitals in southwestern Uganda, April to October 2006 (Continued)

\begin{tabular}{lllll}
\hline Negative & & & 1.0 & \\
\hline Positive & - & - & 2.5 & $0.66,9.1$ \\
\hline Unknown & - & - & $5.8^{*}$ & $1.5,21.4$ \\
\hline
\end{tabular}

${ }^{*}$ Significant at 0.05 level.

will perceive themselves as non-infectious and therefore engage in high-risk sexual behavior.

Our data show that knowledge of sero-status of partner influenced condom use with respondents more likely to report unprotected sexual intercourse when serostatus of partner was not known. Studies elsewhere have shown contrasting findings with less risky sexual practice with partners of unknown sero-status [27]. Among South African couples, awareness of a partner's HIV positive status and HIV positive concordance were associated with protected sex [36]. Yet some studies have shown no difference in risky sexual practice by serostatus of partner [37]. Disclosure of HIV sero-status to the main partner has been associated with safer sexual practices [38]. It should be noted that our study did not establish the nature of these partners, specifically casual versus regular partners and how these may influence use of condoms.

In a Kenyan [25] and Ugandan study [30], women were more likely to report inconsistent condom use compared to the men but this was not the case in our study. In fact there were no gender differences in the frequency of condom use. Also, unlike the study in Kenya, duration of time on ART did not predict the risk of unprotected sex. The reason for these differences is not clear but may be attributed to the nature of the populations under investigation. Majority of women in our study were leading more stable lives and may be less vulnerable compared to women in the informal settlements in the slums of Kibera in Kenya. However, women

Table 4 Multivariable logistic regression of factors associated with unprotected sex among sexually active respondents $(n=168)$ receiving antiretroviral therapy at Kitagata and Mbarara Hospitals

\begin{tabular}{llll}
\hline Predictor & Odds ratio & $\mathbf{9 5 \%} \mathrm{Cl}$ & $\boldsymbol{p}$ value \\
\hline $\begin{array}{l}\text { Any alcohol use in past 6 months } \\
\text { (vs. no consumption) }\end{array}$ & 3.7 & $1.3,10.6$ & 0.012 \\
\hline Serostatus of partner at last intercourse & & & \\
\hline Negative & 1.0 & - & - \\
\hline Positive & 2.3 & $0.62,9.1$ & 0.21 \\
\hline Unknown & 5.5 & $1.4,21.5$ & 0.01 \\
\hline Urban hospital (vs. rural) & 0.93 & $0.43,2.0$ & 0.87 \\
\hline Age younger than 30 & 1.6 & $0.69,3.7$ & 0.27 \\
\hline
\end{tabular}


in our study were more likely to report intercourse with a partner of unknown sero status than men and this may be because of fear of disclosure and the power differential in sexual relationships in this setting. In an African traditional setting, women are unlikely to ask their husbands or partners to go for HIV testing but the opposite is true. This strengthens the cause for emphasizing positive prevention among ART clients and encouragement on disclosure of HIV test results to the partners.

Our study has several limitations, first is that we measured alcohol consumption as a dichotomous outcome. The data collection did not establish the quantities and grade of alcohol consumption so as to determine the dose response relationship. Additionally, our data were not able to support analysis to determine whether the reported high-risk sex was under the influence of alcohol. Second, the high-risk sexual behavior was self-reported and may have been underreported because of a social desirability bias. Third, our study is cross sectional and therefore limited with respect to causal inference. Also, we were unable to characterize the changes in sexual behavior within an individual as the respondents improve.

\section{Conclusion}

In conclusion, our study has shown that younger persons receiving ART are more likely to be sexually active, ART clients are more likely to engage in unprotected sex when serostatus of partner is unknown and if they are consumers of alcohol. We recommend positive prevention and safe sex counseling particularly to clients who use alcohol and encourage disclosure of HIV serostatus among clients whose partners are of unknown status.

\section{Competing interests}

The authors have no competing interests to declare.

\section{Authors' contribution}

FB conceived the idea, participated in data collection, analysis and drafting of the first version of this manuscript and revisions. AKS participated in conception of the idea, data analysis and reviewed the first draft of the manuscript. DRB contributed to conception of the idea, analysis and presentation of results and revision of the first draft of the manuscript. All authors reviewed and approved the final version of the manuscript.

\section{Acknowledgements}

This study was funded by the AIDS International Training and Research Program (AITRP) at Case Western Reserve University through the Fogarty International Center (FIC) at the National Institutes of Health (TW00011). FB receives support from the Harvard Global Scholars program.

\section{Author details}

'Department of Community Health, Mbarara University of Science and Technology, P.O. BOX 1410, Mbarara, Uganda. ${ }^{2}$ Harvard Medical School, Boston, MA, USA. ${ }^{3}$ Center for Global Health, Massachusetts General Hospital, Boston, MA, USA. ${ }^{4}$ Department of Population Health Sciences, University of Wisconsin-Madison, School of Medicine and Public Health, Madison, WI, USA.

Received: 21 December 2012 Accepted: 8 April 2013

Published: 3 May 2013

\section{References}

1. Stangl AL, Wamai N, Mermin J, Awor AC, Bunnell RE: Trends and predictors of quality of life among HIV-infected adults taking highly active antiretroviral therapy in rural Uganda. AIDS Care 2007, 19:626-636.

2. Bajunirwe F, Tisch DJ, King CH, Arts EJ, Debanne SM, Sethi AK: Quality of life and social support among patients receiving antiretroviral therapy in Western Uganda. AIDS Care 2009, 21:271-279.

3. Alibhai A, Martin LJ, Kipp W, Konde-Lule J, Saunders LD, Rubaale T, Houston S, Okech-Ojony J: Quality of life of HIV patients in a rural area of western Uganda: impact of a community-based antiretroviral treatment program. Curr HIV Res 2010, 8:370-378.

4. Dukers NH, Goudsmit J, de Wit JB, Prins M, Weverling GJ, Coutinho RA: Sexual risk behaviour relates to the virological and immunological improvements during highly active antiretroviral therapy in HIV-1 infection. AIDS 2001, 15:369-378.

5. Shafer LA, Nsubuga RN, White R, Mayanja BN, Chapman R, O'Brien K, Van der Paal L, Grosskurth H, Maher D: Antiretroviral therapy and sexual behavior in Uganda: a cohort study. AIDS 2011, 25:671-678.

6. Bruce D, Harper GW, Suleta K: Sexual risk behavior and risk reduction beliefs among HIV-positive young men who have sex with men. AIDS Behav 2013, 17(4):1515-23.

7. Bunnell R, Ekwaru JP, Solberg P, Wamai N, Bikaako-Kajura W, Were W, Coutinho A, Liechty C, Madraa E, Rutherford G, Mermin J: Changes in sexual behavior and risk of HIV transmission after antiretroviral therapy and prevention interventions in rural Uganda. AIDS 2006, 20:85-92.

8. Auvert B, Males S, Puren A, Taljaard D, Carael M, Williams B: Can highly active antiretroviral therapy reduce the spread of HIV?: A study in a township of South Africa. J Acquir Immune Defic Syndr 2004, 36:613-621.

9. Abbas UL, Anderson RM, Mellors JW: Potential impact of antiretroviral chemoprophylaxis on HIV-1 transmission in resource-limited settings. PLoS One 2007, 2:e875.

10. Baggaley RF, Garnett GP, Ferguson NM: Modelling the impact of antiretroviral use in resource-poor settings. PLOS Med 2006, 3:e124

11. Baggaley RF, Ferguson NM, Garnett GP: The epidemiological impact of antiretroviral use predicted by mathematical models: a review. Emerg Themes Epidemiol 2005, 2:9.

12. Biraro $S$, Shafer LA, Kleinschmidt I, Wolff B, Karabalinde A, Nalwoga A, Musinguzi J, Kirungi W, Opio A, Whitworth J, Grosskurth $\mathrm{H}$ : Is sexual risk taking behaviour changing in rural south-west Uganda? Behaviour trends in a rural population cohort 1993-2006. Sex Transm Infect 2009, 85(Suppl 1):i3-11.

13. Shafer LA, Biraro S, Nakiyingi-Miiro J, Kamali A, Ssematimba D, Ouma J, Ojwiya A, Hughes P, Van der Paal L, Whitworth J, et al: HIV prevalence and incidence are no longer falling in southwest Uganda: evidence from a rural population cohort 1989-2005. AIDS 2008, 22:1641-1649.

14. Mbulaiteye SM, Ruberantwari A, Nakiyingi JS, Carpenter LM, Kamali A, Whitworth JA: Alcohol and HIV: a study among sexually active adults in rural southwest Uganda. Int J Epidemiol 2000, 29:911-915.

15. Samet JH, Horton NJ, Meli S, Freedberg KA, Palepu A: Alcohol consumption and antiretroviral adherence among HIV-infected persons with alcohol problems. Alcohol Clin Exp Res 2004, 28:572-577.

16. Weiser SD, Leiter K, Heisler M, McFarland W, Percy-de Korte F, DeMonner SM, Tlou S, Phaladze N, lacopino V, Bangsberg DR: A population-based study on alcohol and high-risk sexual behaviors in Botswana. PLoS Med 2006, 3:e392.

17. Shuper PA, Joharchi N, Irving H, Rehm J: Alcohol as a correlate of unprotected sexual behavior among people living with HIV/AIDS: review and meta-analysis. AIDS Behav 2009, 13:1021-1036.

18. Geibel S, Luchters S, King'Ola N, Esu-Williams E, Rinyiru A, Tun W: Factors associated with self-reported unprotected anal sex among male sex workers in Mombasa, Kenya. Sex Transm Dis 2008, 35:746-752.

19. Hutton HE, McCaul ME, Chander G, Jenckes MW, Nollen C, Sharp VL, et al: Alcohol Use, Anal Sex, and Other Risky Sexual Behaviors Among HIV-Infected Women and Men. AIDS Behav 2012 May 8 [Epub ahead of print].

20. Asiki G, Mpendo J, Abaasa A, Agaba C, Nanvubya A, Nielsen L, Seeley J, Kaleebu P, Grosskurth H, Kamali A: HIV and syphilis prevalence and associated risk factors among fishing communities of Lake Victoria, Uganda. Sex Transm Infect 2011, 87:511-515.

21. Tumwesigye NM, Atuyambe L, Wanyenze RK, Kibira SP, Li Q, WabwireMangen F, Wagner G: Alcohol consumption and risky sexual behaviour in the fishing communities: evidence from two fish landing sites on Lake Victoria in Uganda. BMC Public Health 2012, 12:1069. 
22. Fisher JC, Cook PA, Kapiga SH: Alcohol use before sex and HIV risk: situational characteristics of protected and unprotected encounters among high-risk African women. Sex Transm Dis 2010, 37:571-578.

23. Lane T, Raymond HF, Dladla S, Rasethe J, Struthers H, McFarland W, McIntyre J: High HIV prevalence among men who have sex with men in Soweto, South Africa: results from the Soweto Men's Study. AIDS Behav 2011, 15:626-634.

24. Crepaz N, Marks G: Towards an understanding of sexual risk behavior in people living with HIV: a review of social, psychological, and medical findings. AIDS 2002, 16:135-149.

25. Ragnarsson A, Ekstrom AM, Carter J, llako F, Lukhwaro A, Marrone G, Thorson A: Sexual risk taking among patients on antiretroviral therapy in an urban informal settlement in Kenya: a cross-sectional survey. J Int AIDS Soc 2011, 14:20

26. Apondi R, Bunnell R, Ekwaru JP, Moore D, Bechange S, Khana K, King R, Campbell J, Tappero J, Mermin J: Sexual behavior and HIV transmission risk of Ugandan adults taking antiretroviral therapy: 3 year follow-up. AIDS 2011, 25:1317-1327

27. Dessie Y, Gerbaba M, Bedru A, Davey G: Risky sexual practices and related factors among ART attendees in Addis Ababa Public Hospitals, Ethiopia: a cross-sectional study. BMC Public Health 2011, 11:422.

28. Berhan A, Berhan Y: Is the Sexual Behaviour of HIV Patients on Antiretroviral therapy safe or risky in Sub-Saharan Africa? Meta-Analysis and Meta-Regression. AIDS Res Ther 2012, 9:14.

29. Crepaz N, Hart TA, Marks G: Highly active antiretroviral therapy and sexual risk behavior: a meta-analytic review. JAMA 2004, 292:224-236

30. Wandera B, Kamya MR, Castelnuovo B, Kiragga A, Kambugu A, Wanyama JN, Easterbrook P, Sethi AK: Sexual behaviors over a 3-year period among individuals with advanced HIV/AIDS receiving antiretroviral therapy in an urban HIV clinic in Kampala, Uganda. J Acquir Immune Defic Syndr 2011, 57:62-68.

31. Luchters S, Sarna A, Geibel S, Chersich MF, Munyao P, Kaai S, Mandaliya KN Shikely KS, Rutenberg N, Temmerman M: Safer sexual behaviors after 12 months of antiretroviral treatment in Mombasa, Kenya: a prospective cohort. AIDS Patient Care STDS 2008, 22:587-594.

32. Munoz-Laboy M, Castellanos D, Westacott R: Sexual risk behaviour, viral load, and perceptions of HIV transmission among homosexually active Latino men: an exploratory study. AIDS Care 2005, 17:33-45.

33. Ostrow DE, Fox KJ, Chmiel JS, Silvestre A, Visscher BR, Vanable PA, Jacobson $L P$, Strathdee SA: Attitudes towards highly active antiretroviral therapy are associated with sexual risk taking among HIV-infected and uninfected homosexual men. AIDS 2002, 16:775-780.

34. Stolte IG, Dukers NH, Geskus RB, Coutinho RA, de Wit JB: Homosexual men change to risky sex when perceiving less threat of HIV/AIDS since availability of highly active antiretroviral therapy: a longitudinal study. AIDS 2004, 18:303-309.

35. Diamond C, Richardson JL, Milam J, Stoyanoff S, McCutchan JA, Kemper C, Larsen RA, Hollander H, Weismuller P, Bolan R: Use of and adherence to antiretroviral therapy is associated with decreased sexual risk behavior in HIV clinic patients. J Acquir Immune Defic Syndr 2005, 39:211-218.

36. Peltzer K, Jones D, Weiss SM, Villar-Loubet O, Shikwane E: Sexual risk, serostatus and intimate partner violence among couples during pregnancy in rural South Africa. AIDS Behav 2013, 17(2):508-16.

37. Kelly A, Kupul M, Frankland A, Worth H, Nosi S, Mek A, Kepa B, Walizopa L, Emori R, Pirpir L, et al: Living serodiscordantly in Papua New Guinea: sexual practices of HIV-positive people on ART by serostatus of regular heterosexual partner. AIDS Care 2011, 23:734-740.

38. Loubiere S, Peretti-Watel P, Boyer S, Blanche J, Abega SC, Spire B: HIV disclosure and unsafe sex among HIV-infected women in Cameroon: results from the ANRS-EVAL study. Soc Sci Med 2009, 69:885-891.

doi:10.1186/1471-2458-13-430

Cite this article as: Bajunirwe et al:: Alcohol use and HIV serostatus of partner predict high-risk sexual behavior among patients receiving antiretroviral therapy in South Western Uganda. BMC Public Health 2013 13:430.

\section{Submit your next manuscript to BioMed Central and take full advantage of:}

- Convenient online submission

- Thorough peer review

- No space constraints or color figure charges

- Immediate publication on acceptance

- Inclusion in PubMed, CAS, Scopus and Google Scholar

- Research which is freely available for redistribution 